\title{
Genetic Parameters of Interspecific Hybrids of Eucalyptus grandis and E. urophylla Seedlings and Cuttings
}

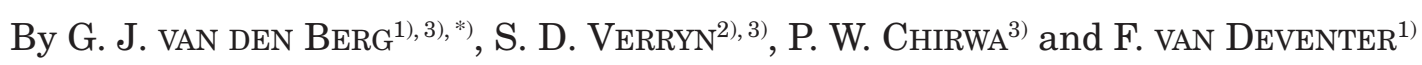

(Received $4^{\text {th }}$ January 2016)

\begin{abstract}
The current $E$. grandis x $E$. urophylla hybrid breeding strategy of South Africa's Forestry Industry is to maintain large breeding populations of both parental species in which parents are selected based on their general combining ability (GCA) estimates or predicted individual tree breeding values and are used for interspecific hybrid crosses. The hybrid material is first screened in seedling progeny trials after which superior individuals are selected and tested as clones. Although this strategy has delivered superior clones for commercial production in South Africa, it is a time consuming strategy to follow and more cost effective strategies are being investigated. In order to review the current hybrid breeding strategy, information on the genetic control of the traits of interest is needed for $E$. grandis x $E$. urophylla seedling and clonal populations. The main objectives of this study were therefore to firstly estimate genetic parameters for $E$. grandis x $E$. urophylla hybrid seedling and clonal populations; secondly to investigate the correlation between $E$. grandis and E. urophylla parental (GCA) or individual breeding values and their general hybridising ability (GHA); and lastly to determine the correlation between $E$. grandis $\mathrm{x}$ $E$. urophylla hybrid seedling ortets and their ramets.
\end{abstract}

Results of our study indicated that non-additive genetic variation explained the majority of the total genetic variation in $E$. grandis $\mathrm{x}$ E. urophylla seedling and clonal populations. Due to the pre-eminence of non-additive vari-

1) Mondi Forests (Pty) Ltd, P.O. Box 12, Hilton, 3245, South Africa.

$\left.{ }^{2}\right)$ Creation Breeding Innovations cc, 75 Kafue Street, Lynnwood Glen, Pretoria, 0081, South Africa.

3) Faculty of Natural and Agricultural Sciences, University of Pretoria, 2 Lynnwood Road, Hatfield, Pretoria, 0002, South Africa.

*) Corresponding author: G. J. VAN DEN BERG. E-Mail: gert.vandenberg@mondigroup.co.za ance, the pure-hybrid correlations were weak, especially for clonal populations. It would therefore seem that GCA or predicted individual breeding values are not good predictors of GHA for growth performance in the observed populations. Our study also indicated a weak coefficient of correlation between the growth performance of seedling ortets and their ramets. These results suggest that: firstly a hybrid breeding strategy to capture non-additive genetic variation should be adopted; and secondly that the first phase of screening $E$. grandis x $E$. urophylla hybrid material as seedlings should be revisited.

Key words: Eucalyptus grandis x E. urophylla; genetic parameters; seedlings and cuttings; pearson correlations.

\section{Introduction}

The deployment of interspecific hybrids in commercial forest tree planting is prevalent worldwide (KERR et al., 2004). There are many reports on the superiority of Eucalyptus interspecific hybrids (DENISON and KIETZKA, 1993; De Assis, 2000; KHA and CuONG, 2000; PotTs et al., 2000; VERRYN, 2000; VigNERON et al., 2000; PotTs and Dungey, 2004; Bison et al., 2006). Interspecific hybrids of $E$. urophylla and $E$. grandis in particular, have been used in tropical and subtropical forestry for a while, especially in Brazil (IKEMORI, 1984; Bison et al., 2006), Congo (Vigneron and Bouvet, 2000) and South Africa (RETIEF and STANGeR, 2009). Eucalyptus grandis suffers from fungal diseases, in particular, Crysoporthe austroafricana and Coniothyrium sp. cankers in these tropical and subtropical regions. However, the interspecific hybrids with $E$. urophylla have shown to be more resistant to the diseases of concern.

The current $E$. grandis x $E$. urophylla hybrid breeding strategy of South Africa's Forestry 
Industry is an adaption to the classic hybrid breeding strategy namely "Recurrent Selection for General Combining Ability (RS-GCA; JENKINS, 1940). Large breeding populations of both parental species are maintained and elite selections are made based on either the parents GCA estimates (backward selection) or predicted individual tree breeding values (forward selection). General combining ability is a measure of the genetic worth of a parent based on the average performance of the progeny from a particular parent, whereas predicted individual breeding values is an estimation of the genetic worth of individuals based on their own performance, and that of their sibs (HETTASCH et $a l ., 2005)$. Selected parents are used for interspecific hybrid crosses, and the hybrid material is first tested as seedlings in seedling progeny trials. Superior individuals are selected at midrotation from the seedling populations and ramets of the ortets are then tested as clones in clonal trials.

The underlying research hypothesis of the above mentioned strategy is firstly that GCA or predicted individual tree breeding values are good predictors of GHA. General hybridising ability is a measure of the genetic worth of a hybrid parent based on the average performance of the hybrid progeny from the parent when crossed with various parents of a different species (Hettasch et al., 2005). The correlation between GCA and GHA is a useful indicator of the consistency of parental performance when used as a hybrid parent compared to when the same selections are used as pure species parents. If this hypothesis is false, then a hybrid breeding strategy such as Reciprocal Recurrent Selection (RRS; CoMSTOCK et al., 1949) has obvious advantages (VIGNERON and BOUVET, 2000). Although some authors indicated a poor correlation between GCA and GHA (RETIEF and STANGER, 2009; VOLKER et al., 2008), literature related to this topic is sparse and more information regarding this is needed. For instance, results of the latter studies were based on the performance of seedling populations and not clonal populations. In most countries, interspecific hybrids of $E$. grandis $\mathrm{x} E$. urophylla are commercially deployed as clones. Hence genetic information on $E$. grandis $\mathrm{x} E$. urophylla clonal populations needs to be determined.

The second underlying hypothesis of the current breeding strategy is that the perform- ance of the seedling ortet is a good predictor of its ramets performance. Although some authors (FUller and LitTle, 2007; GASPAR et al., 2005; SASSE and SANDS, 1996) reported that there was no significant difference between eucalypt cuttings and seedlings for growth, no direct comparison of ortets and their ramets have been reported on. All of these studies produced cuttings from different individuals with a similar genetic makeup than that of the seedlings. Hence, the general theoretical literature on this subject and specifically in the context of $E$.grandis x $E$. urophylla hybrid populations is inconclusive and needs further investigation.

In addition, the magnitude of specific combining effects in the hybrid crosses (SHA) is also one of the most important factors to consider when developing a hybrid breeding strategy (VOLKER, 2002) and needs investigation. With this in mind, our study was set out to address the following scientific questions:

- What is the correlation between the parent's performance as a pure species (GCA or individual tree breeding values) and in a hybrid combination (GHA) in seedling and clonal populations?

- What is the magnitude of specific combining effects in the hybrid seedling and clonal populations?

- Is the performance of the seedling ortet a good predictor of the ramets performance?

Answers to these questions will provide valuable information to hybrid tree breeders around the world and will assist to construct suitable Eucalyptus hybrid breeding strategies. The objectives of this study were therefore to:

- Determine the Pearson correlation between E. grandis and E. urophylla parents (GCA or predicted individual tree breeding values) and their hybrid (GHA) progeny (seedlings and clones).

- Estimate genetic parameters for $E$. grandis x E. urophylla hybrid seedling and clonal populations.

- Calculate the Pearson correlation between $E$. grandis $\mathrm{x} E$. urophylla hybrid seedling ortets (predicted individual tree breeding values) and their ramets (mean best linear unbiased predictions (BLUP). 


\section{Materials and methods}

\section{Breeding material}

Seedling population

The mating design consisted of a partial factorial with $30 E$. grandis parents (female) and 27 E. urophylla parents (male) (Figure 1). A total of $108 E$. grandis $\times E$. urophylla families were produced and established in progeny seedling trials. Although only $13 \%$ of the cells of the factorial mating were completed, $15 E$. grandis and $15 E$. urophylla parents were crossed between 3 and 14 times. Sixty nine of the 108 $E$. grandis x $E$. urophylla families were planted at 2 or more sites. All the parents were selected on their mature age phenotypes for growth and tree form. The $E$. grandis parents are cloned selections made in a second generation (F2) progeny trial series from the South Africa Forestry Research Institute programme (as it was called at the time). The $E$. urophylla parents used in this study are all cloned selections from an unimproved (P0) provenance/progeny trial series of open-pollinated seed collected from different provenances on Indonesian Islands.
Clonal population

A total of 148 selections were made from 63 families (Table 1) from the above mentioned $E$. grandis $\mathrm{x} E$. urophylla seedling population. All trees were selected on their mature age phenotypes for growth and tree form. Multiple cuttings were produced from each selection and were established in a series of clonal trials at a minimum of 6 sites.

\section{Trial establishment and measurements}

Seedling population

Three series of trials (PE062A\&B, PE80A\&B\&C and PE109A\&B) were established in the subtropical region of South Africa, namely Zululand. Site and trial information for each trial is presented in Table 2. Each trial was planted in a randomised complete block design (RCB). Trial measurements were scheduled at mid-rotation (3-4 years) and at rotation age (7-8 years). Growth traits namely: height in metres and diameter at breast height, $(\mathrm{DBH}$, in centimetres) were taken and tree volume was calculated using the following equation as described by MAX and BURKHART (1976):

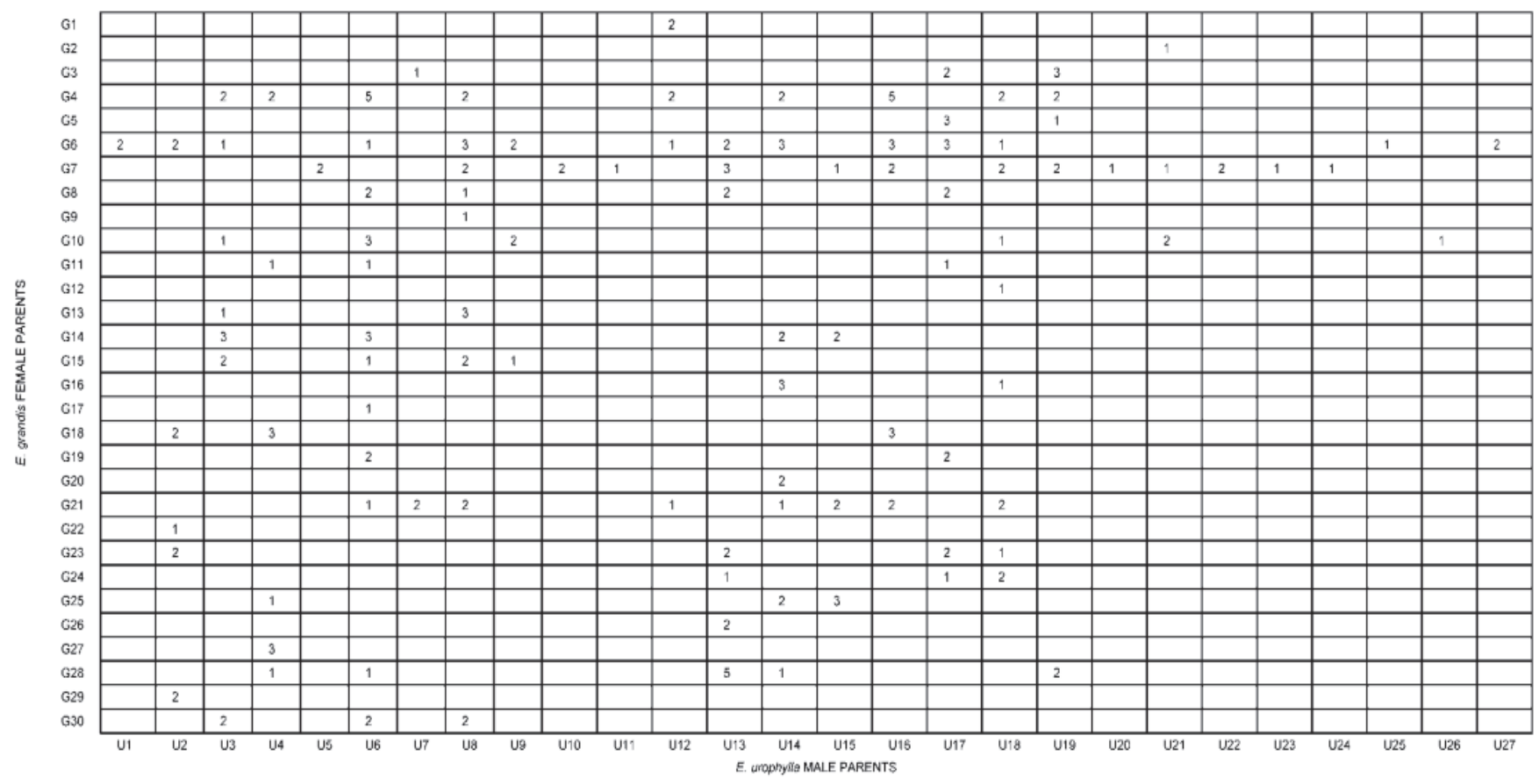

Figure 1. - Diagram indicating Eucalyptus grandis x E. urophylla crosses in the mating design of the partial factorial. The numbers of sites where the hybrid families were established as seedlings are designated by the number in the cell. 
Volume $=\left(\frac{\pi}{40000}\right) * \mathrm{k}^{*} D B H^{2 *}$ Height

Where,

$\mathrm{k}=\left(\frac{\beta_{1}}{3}\right)+\left(\frac{\beta_{0}}{2}\right)-\left(\beta_{0}+\beta_{1}\right)+\left(\frac{\beta_{2}}{3}\right)^{*} a_{1}^{3}+\left(\frac{\beta_{3}}{3}\right)^{*} a_{2}^{3}$

$\beta_{0}=-2.72108$

$\beta_{1}=1.18891$

$\beta_{2}=-0.90650$

$\beta_{3}=95.42845$

$\alpha_{1}^{3}=0.83117$

$\alpha_{2}^{3}=0.059583$

Functions used in the equation were developed internally by Mondi Limited (KотZE and FLETCHER, unpublished data).
Clonal population

Three E. grandis x E. urophylla clonal trial series (IC358A-F, IC361A-F and IC365A-H) were established across various sites at Zululand. Site and trial information for each trial site is presented in Table 3. Each trial was planted in a RCB design. Height and DBH were measured at four and seven years of age. Only four year data were available for the IC365 trial series. Tree volume was calculated using the same equation described for the seedling population.

\section{Statistical analysis}

Descriptive statistics

In order to compute the descriptive statistics of each trial site for all the growth traits, PROC

Table 1. - Number of selections made from E. grandis $\mathrm{x} E$. urophylla families and the number of clonal trials established with clonal material from each family.

\begin{tabular}{|c|c|c|c|c|c|}
\hline Family & No. of selections & $\begin{array}{c}\text { No. of clonal } \\
\text { trials }\end{array}$ & Family & No. of selections & No. of clonal trials \\
\hline G1xU12 & 1 & 6 & G10xU3 & 2 & 8 \\
\hline G3xU17 & 3 & 6 & G10xU6 & 2 & 6 \\
\hline G3xU19 & 1 & 6 & G10xU21 & 1 & 8 \\
\hline $\mathrm{G} 4 \mathrm{~K} \cup 3$ & 3 & 6 & G10xU26 & 1 & 6 \\
\hline G4xU6 & 1 & 6 & G11xU6 & 1 & 6 \\
\hline 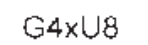 & 9 & 6 & G13xU3 & 1 & 6 \\
\hline $\mathrm{G} 4 \times \mathrm{U} 12$ & 4 & 6 & G13xU8 & 2 & 6 \\
\hline G4xU16 & 4 & 6 & G14xU6 & 1 & 6 \\
\hline G4xU18 & 7 & 6 & G14xU14 & 2 & 6 \\
\hline G4xU19 & 1 & 6 & G14xU15 & 2 & 6 \\
\hline G5xU17 & 2 & 6 & G15xU8 & 5 & 6 \\
\hline G6xU1 & 5 & 6 & G15xU9 & 1 & 8 \\
\hline G6xU8 & 2 & 6 & G16xU14 & 7 & 6 \\
\hline G6xug & 1 & 8 & G18xU16 & 1 & 6 \\
\hline G6xU13 & 1 & 8 & G19xU6 & 1 & 6 \\
\hline G6xบ14 & 2 & 6 & G20xU14 & 3 & 6 \\
\hline G6xU16 & 1 & 6 & G21xU14 & 2 & 6 \\
\hline G6xU17 & 1 & E & $\mathrm{G} 21 \times \cup 15$ & 2 & 6 \\
\hline G6xU18 & 2 & 6 & G21XU16 & 1 & 6 \\
\hline G6xU27 & 5 & 6 & G21xU18 & 2 & 6 \\
\hline G7xU5 & 4 & 6 & $\mathrm{G} 23 \times \mathrm{U} 2$ & 4 & 6 \\
\hline G7xU8 & 7 & 6 & $\mathrm{G} 23 \times \mathrm{U} 13$ & 1 & 6 \\
\hline G7xU10 & 1 & 8 & G23xU17 & 2 & 6 \\
\hline G7xU13 & 3 & 0 & G23xU18 & 1 & 6 \\
\hline G7xU18 & 2 & 8 & G24XU18 & 1 & 6 \\
\hline G7×U19 & 3 & 6 & G25xU14 & 4 & 6 \\
\hline G7xU2O & 1 & 6 & $\mathrm{G} 27 \times \mathrm{U}_{4}$ & 1 & 6 \\
\hline G7xU21 & 1 & 8 & G28xU13 & 1 & 6 \\
\hline $\mathrm{G} 7 \times \mathrm{U} 22$ & 1 & 8 & G28xU19 & 5 & 6 \\
\hline $\mathrm{G} 7 \times \cup 23$ & 1 & 8 & $\mathrm{G} 29 \times \mathrm{U} 2$ & 1 & 6 \\
\hline G8xU13 & 1 & 6 & G30xU8 & 1 & 8 \\
\hline G8xU17 & 5 & 6 & & & \\
\hline
\end{tabular}


Table 2. - Site and trial information of Eucalyptus grandis x E. urophylla hybrid seedling trials.

\begin{tabular}{|c|c|c|c|c|c|c|c|}
\hline & PE062A & PE062B & PEO80A & PE080B & PE080C & PE 109A & PE109B \\
\hline Longitude & $32^{\prime \prime} 12^{\prime} E$ & $31^{\prime \prime} 42^{\prime} E$ & $32^{\prime \prime} 11^{\prime} \mathrm{E}$ & $31^{\prime \prime} 42^{\prime} \mathrm{E}$ & $32^{\prime} 20^{\prime} \mathrm{E}$ & $32^{\circ} 06^{\prime} \mathrm{E}$ & $32^{\circ} 06^{\prime} \mathrm{E}$ \\
\hline Latitude & $28^{\circ} 34^{\prime} 5$ & $29^{\circ} 00^{\prime} \mathrm{S}$ & $28^{\circ} 35^{\prime} \mathrm{S}$ & $28^{\circ} 59^{\prime} \mathrm{S}$ & $2 g^{\circ} 16^{\prime} s$ & $28^{\circ} 38^{\prime} \mathrm{s}$ & $28^{\circ} 38^{\prime} 5$ \\
\hline M.A.P. $(m m)$ & 1156 & 1273 & 1271 & 1201 & 1050 & 1079 & 1079 \\
\hline M.A.T $\left({ }^{\circ} \mathrm{C}\right)$ & 21.2 & 21.4 & 21.6 & 21 & 215 & 21.3 & 21.6 \\
\hline Altitude (m) & 40 & 40 & 40 & 40 & 20 & 55 & 55 \\
\hline Major soil type & Fw 1110 & $\mathrm{H} u 26$ & Fw 1110 & $\mathrm{Hu} 26$ & Fw 2110 & $\mathrm{Ct} 2100$ & Ct 2100 \\
\hline $\begin{array}{l}\text { Effective rooting } \\
\text { depth (m) }\end{array}$ & 1.51 & 1.51 & 1.51 & 1.51 & 1.51 & 1.51 & 1.51 \\
\hline Planting date & $22 / 07 / 94$ & $28 / 07 / 94$ & $03 / 10 / 96$ & $11 / 10 / 96$ & $03 / 10 / 96$ & $25 / 06 / 98$ & $25 / 06 / 98$ \\
\hline Espacement & $3 m \times 2 m$ & $3 m \times 2 m$ & $3 m \times 2 m$ & $3 \mathrm{~m} \times 2 \mathrm{~m}$ & $3 m \times 2 m$ & $3 m \times 2 m$ & $3 m \times 2 m$ \\
\hline Ferriliser & $\begin{array}{c}4: 1: 1 @ 0 \\
200 \mathrm{~g} \text { tree }\end{array}$ & $\begin{array}{c}4: 1: 1 @ \\
200 \mathrm{~d} / \text { tree }\end{array}$ & $\begin{array}{c}420 @ \\
200 \text { o'tree }\end{array}$ & $\begin{array}{l}5: 2: 0 @ \\
70 \mathrm{~g} / \text { tree }\end{array}$ & $\begin{array}{l}\text { No } \\
\text { fertiliser }\end{array}$ & $\begin{array}{l}\text { No } \\
\text { fertiliser }\end{array}$ & $\begin{array}{c}\text { No } \\
\text { fertiliser }\end{array}$ \\
\hline Replications & 5 & 5 & 6 & 6 & 1 & 12 & 12 \\
\hline Plot size & $1 \times 6$ tree line & $1 \times 6$ tree line & $1 \times 6$ tree line & $1 \times \hat{0}$ tree line & $\begin{array}{l}\text { Single } \\
\text { tree }\end{array}$ & Single tree & $\begin{array}{l}\text { Single } \\
\text { tree }\end{array}$ \\
\hline Number of families & 39 & 36 & 48 & 34 & 29 & 33 & 19 \\
\hline
\end{tabular}

MEANS in SAS (SAS INSTITUTE, 2002) was used. The descriptive analysis was done prior to the standardisation of the data.

\section{Standardisation of data}

Forest trees often display heterogeneous variances for growth traits where a strong relationship between the mean of the trait and its phenotypic and genetic variances are seen. This relationship is such that the field trials with bigger trees will have larger phenotypic and genetic variances than the field trials with smaller trees even if the trials are at the same age (HODGE and DvORAK, 2012).In order to deal with these differences in scale, WHITE et al. (2007) recommend data standardisation prior to analysis of variances, variance component analysis, or multi-site mixed model analysis. The standardisation of data homogenised variances that were used together in the linear model and eliminated any spurious genotype $\mathrm{x}$ environment interaction (GxE) (BURDON, 1977; Eisen and SAXON, 1983; HILL, 1984). The standardisation for the analysis of this paper was performed as described by HoDGE and DVORAK (2012). First, the coefficient of variation (CV) was calculated for each growth trait for each replication at each site. The mean coefficient of variances $\left(\mathrm{CV}_{\mathrm{y}}\right)$ for each family-site-trait combination was also calculated. The phenotypic observations were then standardised with PROC STANDARD in SAS (SAS INSTITUTE, 2002) for each replication at each site to a mean $=100$, and with a standard deviation of $=100 \times \mathrm{CV}_{\mathrm{y}}$. This is equal to dividing all observations by the phenotypic standard deviation (SD), as recommended by WHITE et al. (2007), followed by adding a constant (100\%) and multiplying by a constant $\left(100 \times \mathrm{CV}_{\mathrm{y}}\right)$. The population mean for the growth trait can therefore be interpreted as $100 \%$, and the associated variances and SD are the same size relative to mean as in the raw data. Predicted breeding values and all variance components can thus be directly interpreted as percentage gain (above or below $100 \%$ ) without back-transformation or rescaling.

\section{Analysis of the $E$. grandis $\mathrm{x} E$. urophylla} seedling population

The statistical model used for the factorial was as follows:

$$
y_{i j k l m}=\mu+S_{i}+R_{j(i)}+f_{k}+m_{l}+f m_{k l}+\mathrm{S}_{\mathrm{i}}^{*} f m_{i k l}+e_{i j k l m}
$$

Where,

$y_{i j k l m}=$ the $m^{\text {th }}$ observation of the $j^{\text {th }}$ replication for the $k l^{\text {th }}$ family at the $i^{\text {th }}$ site;

$\mu \quad=$ overall mean;

$S_{i} \quad=$ fixed effect of the $i^{t h}$ site;

$R_{j(i)} \quad=$ fixed effect of the $j^{\text {th }}$ replication within the $i^{\text {th }}$ site;

$f_{k}$ or $m_{l}=$ the random GHA effect for the $k^{\text {th }}$ female or the $l^{\text {th }}$ male;

$\mathrm{fm}_{k l} \quad=$ random specific hybridising ability (SHA) effect of the $k^{\text {th }}$ and $l^{\text {th }}$ parents;

$S_{i}^{*} f m_{j k l}=$ random SHA by Site Interaction;

$e_{i j k l m}=$ random within plot error term. 
Table 3. - Site and trial information of E. grandis x E. urophylla hybrid clonal trials.

\begin{tabular}{|c|c|c|c|c|c|c|c|c|}
\hline \multicolumn{9}{|c|}{ IC358 C ONAL TR/AL SEFIES } \\
\hline$T \cdot$ ial & IC.358. A & 10358.9 & $16355 \mathrm{C}$ & $10.358]$ & IC.358F & |C.SEBF & & \\
\hline _ongit..de & $32^{\circ} 06 \mathrm{E}$ & $32^{\circ} 0 \mathrm{E}$ & $31 \cdot 42 \equiv$ & $31: 43^{\prime} E$ & $31: 53 \mathrm{E}$ & $31.50 \mathrm{E}$ & & \\
\hline Latitude & $23^{2} 31 \mathrm{~s}$ & $2 a^{\prime} 3$ & 2859 & $2 \mathrm{~B}^{\prime} 5 \mathrm{~g}^{\prime} \mathrm{S}$ & $2 y^{3} 52 \mathrm{~s}$ & $2 \mathrm{G}^{\prime} 5 \mathrm{~J}^{\prime} \mathrm{S}$ & & \\
\hline M.A.F. (mm) & $1084 \mathrm{~mm}$ & $1051 \cdot \mathrm{hrr}$ & $1293 \mathrm{~m}$ & $1295 \mathrm{~mm}$ & $1379 \mathrm{Tir}$ & $1476 \cdots n$ & & \\
\hline В & $216^{\circ} \mathrm{C}$ & $216=0$ & $211^{\circ} \mathrm{C}$ & $211 \mathrm{C}$ & 2130 & $2 \cdot 0$ & & \\
\hline Altitude; '? & bh r & 39 тा & $24 \mathrm{~m}$ & $4 \pi$ & $\theta_{2}^{2} r \mathrm{r}$ & $96 \mathrm{~m}$ & & \\
\hline Majcr soil lype & Kud?aco & Fw1210 & $\mathrm{H}_{\lrcorner} 27$ & $\mathrm{H} \sqcup 25$ & 니 2200 & Hu 2200 & & \\
\hline 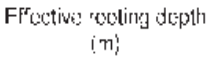 & $7-1.4 m^{m}$ & 1.51 & 1.21 & 1.21 & 1.5 & 5 & & \\
\hline Flant na cate: & 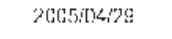 & 7005105090 & $700506: 1 ?$ & $2005: 3044$ & 20050613 & 20050705 & & \\
\hline Espuctentent & $3 \pi x 2 \pi$ & $3 r \times 2 \pi$ & $3 \pi 1 \times 27$ & $3 \Gamma 17 \times 2+1$ & $3 \pi \times 2 \pi$ & $3 \mathrm{rr} \times 2 \mathrm{~m}$ & & \\
\hline Replicat ons & 20 & 20 & 23 & $2=$ & 21 & 20 & & \\
\hline F'|э: size & single tree & Sing e tree & Sirçle tree & 5 -gle :ree & Single tree & Solngle tree & & \\
\hline Nurbere of o oness & 68 & 68 & 68 & 68 & 68 & 68 & & \\
\hline \multicolumn{9}{|c|}{$|C 3910.04 A|$ TRIAL SFFIFS } \\
\hline T'al & IC.361A & 163513 & 103510 & 163513 & ICO361E & $\mid \operatorname{cse} 1 \Gamma$ & & \\
\hline ongit. Ine & $3 \% 1 \gamma^{\prime} \mathrm{E}$ & $3 \%$ ด 1 & $31^{2} 58^{\prime}$ & $31 " 45 y^{\prime}+$ & $31 " 411$ & $31^{\prime} 4 \%$ & & \\
\hline Latitude & $28^{\prime} 36^{\prime} 8$ & $26^{\circ} 39$ & $28^{\prime} 44^{\prime} 9$ & $28^{\prime} 54^{\prime} \mathrm{S}$ & $29=60^{\prime} 9$ & $28^{\circ} 50^{\prime} 8$ & & \\
\hline M.A.P. (rmIn!! & 1201 & -116 & 1138 & 400 & 1273 & 1259 & & \\
\hline И.AT. O & 2.6 & 21.5 & 21.3 & 21.1 & 21 & 21.1 & & \\
\hline Altitude 'm! & 55 & 71 & 76 & 79 & 6 & 47 & & \\
\hline $\begin{array}{l}\text { Elective coling depth } \\
\qquad, !)\end{array}$ & 45 & 151 & 121 & 151 & 15 & $05-08$ & & \\
\hline Plant ng cate & 2 CCOCOLZ & $2000109: 27$ & $2006159 ; 15$ & 20051026 & 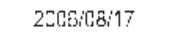 & 2000108:18 & & \\
\hline 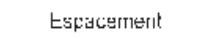 & $3\left[x x^{2}\right.$ & $3 \Gamma \times 2 \pi$ & $\sin \times 2 \cdots$ & $3 \mathrm{rr} \times 2 \mathrm{r}$ & $3 \pi \times 2 \pi$ & $3 \times \times 2$ & & \\
\hline Fertilser & DAPG abgitee & DAF Gogitre & DA= (a) bogitre & DA $=$ II 60 gitree & DAP G 6lghtee & EAP Gogtres & & \\
\hline Iecpilatat nas & \%! & 20 & $p$ & $2 n$ & ? & 20 & & \\
\hline FNat: size & Single tree & Sing e tree & Sirgle tree & Sj - gle tree & Single tree & Single tree & & \\
\hline Nurber af $c$ ones & 85 & 85 & 85 & 55 & 85 & 85 & & \\
\hline \multicolumn{9}{|c|}{ ICJ35 C_OAAL IR/AL SERILS } \\
\hline $\mathrm{T} \cdot \mathrm{al}$ & 103652 & 103559 & 163556 & $\mid \operatorname{C35} 5 \overline{1}$ & IC365F & $1 \mathrm{CB} 65 \mathrm{~F}$ & $10365 \mathrm{G}$ & 103554 \\
\hline ongit.ıtre & $32^{011:=}$ & 326 DE F & $32^{6} \mathrm{ar} F$ & $3 \times 507 \mathrm{~F}$ & $31^{i} 43 \mathrm{~F}$ & $21^{\circ} \mathrm{s:} \mathrm{F}$ & $3^{6} \mathrm{Dg} \mathrm{F}$ & $31^{3} 15^{\circ} \mathrm{F}$ \\
\hline Latitıde & $28^{\circ} 30^{\circ} \mathrm{s}$ & $28^{5} 33 \mathrm{~s}$ & $28^{\circ} 18^{\circ} \mathrm{s}$ & $28^{2} 53^{\prime} \mathrm{S}$ & $2 \mathrm{e}^{\prime} 5 \mathrm{~g} \mathrm{~s}$ & $28^{\circ} 51^{1} \mathrm{~S}$ & $2 g^{2} 4 ! s$ & $2 u^{-} Z 1^{\prime} s$ \\
\hline W.A.F. Imm & 917 & 2008 & 1020 & 524 & 1266 & 1370 & 471 & 1030 \\
\hline A A 1 C & $\nu^{8}$ & 216 & $r$ & 215 & $m$ & 216 & 215 & 715 \\
\hline Altitude: & ؛1 & 11 & is & $4 i$ & $4 i$ & 9.6 & 52 & $4:$ \\
\hline M:jor soil type & $F w 1110$ & Fw1210 & $=m 140$ & $F w 210$ & $K: 10$ & 442109 & $\mathrm{~V} / 21^{-} \mathrm{Li}$ & Fw1110 \\
\hline $\begin{array}{c}\text { ГFective recting depth } \\
\qquad \mathrm{mi}\end{array}$ & 151 & 151 & 51 & 15 & 50 & 151 & 151 & 151 \\
\hline Plant ng catc & 20050530 & $2009: 06: 18$ & 20090603 & $20591 \% 630$ & 27050722 & 20090900 & $205069 / 21$ & 200019422 \\
\hline Espacoment & $3 \pi \times 2 m$ & $3 \Gamma^{-} \times 2 \pi$ & $\sin x 2 \pi$ & $3 \sqcap \times 27$ & $37 \times 2 m$ & $I_{\pi} \times 2 \pi$ & $3 п x \geq \pi$ & $3 m \times 27$ \\
\hline Frrtil ser & $A N O B$ & IAR PB: & I AN & $1 A N(28)$ & I $A N P 8)$ & I AN ?PB! & (AN PQ) & I AN? 29 ! \\
\hline Feplitat mis & 15 & 15 & 15 & 45 & 15 & 15 & 1.5 & 15 \\
\hline HIJ size & single tree & Sing e Iree & sirgle tree & 5 ngle ree & Singla tree & sj'igle tree & Srgle tree & Single tree \\
\hline
\end{tabular}


All effects, except the overall mean, site and replication effect, were assumed to be random and independently distributed. A mixed model using PROC MIXED (SAS InstituTe, 2002) in SAS was used to estimate variance components and to obtain BLUP estimates of random genetic effects (GHA and SHA) simultaneously. Restricted maximum likelihood (REML) was used in order to maximise the likelihood of the sample residuals. Wald test was used to determine the significance of the random effects.

The relationship between variance components derived from the quantitative genetic model was used to estimate the additive and dominance variance (FALCONER, 1981).

$\hat{\sigma}_{f}^{2}=$ variance due to the female effect,

$\hat{\sigma}_{A f}^{2}=4 \hat{\sigma}_{A f}^{2}$ is the additive variance due to the female effect,

$\hat{\sigma}_{m}^{2}=$ variance due to the male effect,

$\hat{\sigma}_{A m}^{2}=4 \hat{\sigma}_{m}^{2}$ is the additive variance due to the male effect,

$\hat{\sigma}_{A}^{2}=1 / 2\left(\hat{\sigma}_{A f}^{2}+\hat{\sigma}_{m}^{2}\right)$ is the additive variance combining the female and male effect,

$\hat{\sigma}_{f m}^{2}=$ variance due to the family effect,

$\hat{\sigma}_{D}^{2}=4 \hat{\sigma}_{f m}^{2}$ is the dominance variance,

$\hat{\sigma}_{G}^{2}=\hat{\sigma}_{A}^{2}+\hat{\sigma}_{D}^{2}$ is the total genetic variance,

$\hat{\sigma}_{\text {total }}^{2}=\hat{\sigma}_{G}^{2}+\hat{\sigma}_{e}^{2}$ is the total phenotypic variance.

Heritabilities were estimated as:

$h_{f}^{2}=\frac{\widehat{\sigma}_{A f}^{2}}{\hat{\sigma}_{\text {total }}^{2}}$

is the narrow-sense heritability for the female half-sibs,

$h_{m}^{2}=\frac{\widehat{\sigma}_{A m}^{2}}{\widehat{\sigma}_{\text {total }}^{2}}$

is the narrow-sense heritability for the male half-sibs,

$h_{i}^{2}=\frac{\widehat{\sigma}_{A}^{2}}{\partial_{\text {total }}^{2}}$

is the narrow-sense heritability for the combined female and male hybrid parents,

$d^{2}=\frac{\widehat{\sigma}_{D}^{2}}{\hat{\sigma}_{\text {total }}^{2}}$

is the ratio of dominance variance to total individual phenotypic variance,

$H_{i}^{2}=\frac{\widehat{\sigma}_{G}^{2}}{\hat{\sigma}_{\text {total }}^{2}}$ is the broad-sense heritability on an individual basis,

Standard errors of heritabilities were calculated by Dickerson's approximation (DICKERSON, 1969).

In order to determine the genetic correlations of the same trait expressed on multiple sites as described by BURDON (1977), type B genetic correlations were estimated as:

$$
r_{B f m}=\frac{\widehat{\partial}_{f m}^{2}}{\hat{\sigma}_{f m}^{2}+\widehat{\sigma}_{s * f m}^{2}}
$$

is the type B genetic correlation for the full-sib families.

Where,

$\hat{\sigma}_{f m}^{2} \quad=$ variance due to the family effect;

$\hat{\sigma}_{s * f m}^{2}=$ variance due to the family by site interaction effect.

Type B correlation estimates the magnitude of GxE that is due to rank changes across environments. This correlation over multiple sites can range between zero and one. An $r_{B}=1$ predicts a perfect correlation between performance in different environments. In tree breeding, the generally accepted type $\mathrm{B}$ correlation estimate is equal to 0.7 (HeTtasch et al., 2005).

The Pearson correlation coefficient between the GCA of $E$. grandis parents and the GHA of their interspecific hybrid progeny was estimated by using PROC CORR (SAS INSTITUTE, 2002 ) in SAS. In the case of $E$. urophylla parents however, intraspecific progeny were not available to calculate the GCA values of the E. urophylla parents. Instead, individual tree breeding values were used for estimating the above mentioned correlation coefficient. The individual tree breeding values of the $E$. urophylla pure species parents were estimated using BLUP analysis (VAN DEN BERG et al., 2016).

\section{Analysis of the E. grandis $x E$. urophylla clonal population}

The statistical model used for the factorial was as follows:

$$
\begin{aligned}
y_{i j k l m n}= & \mu+S_{i}+R_{j(i)}+f_{k}+m_{l}+f m_{k l}+ \\
& C_{m}+S_{i} * f m_{i k l}+S_{i}{ }^{*} c_{i m}+e_{i j k l m n}
\end{aligned}
$$


Where,

$y_{i j k l m n}=$ the $n^{\text {th }}$ observation of the $j^{\text {th }}$ replication for the $k l^{t h}$ family for the $m^{\text {th }}$ clone at the $i^{t h}$ site;

$\mu \quad=$ overall mean;

$S_{i} \quad=$ fixed effect of the $i^{\text {th }}$ site;

$R_{j(i)} \quad=$ fixed effect of the $j^{\text {th }}$ replication within the $i^{\text {th }}$ site;

$f_{k}$ or $m_{l}=$ the random GHA effect for the $k^{t h}$ female or the $l^{\text {th }}$ male;

$f m_{k l}=$ random SHA effect of the $k^{t h}$ and $l^{t h}$ parents;

$C_{m} \quad=$ random effect of the $m^{\text {th }}$ Clone;

$S_{i}{ }^{*} f m_{j k l}=$ random SHA by Site Interaction;

$S_{i}{ }^{*} c_{m} \quad=$ random Clone by Site Interaction;

$e_{i j k l m}=$ random within plot error term.

All effects, except the overall mean, site and replication effect, were assumed to be random and independently distributed. As with the seedling population, PROC MIXED (SAS INSTITUTE, 2002) in SAS was used to estimate variance components and to obtain BLUP of random genetic effects (GHA, SHA and clone) simultaneously. Additive genetic variance, dominance genetic variance and heritabilities were calculated the same way as for the hybrid seedling population with the following exceptions:

$\hat{\sigma}_{N A}^{2}=\hat{\sigma}_{D}^{2}+\hat{\sigma}_{C}^{2}$ is the total non-additive genetic variance,

$\hat{\sigma}_{G}^{2}=\hat{\sigma}_{A}^{2}+\hat{\sigma}_{N A}^{2}$ is the total genetic variance,

The ratio of clone variance to total individual phenotypic variance was estimated as: $c^{2}=\frac{\widehat{\sigma}_{c}^{2}}{\widehat{\sigma}_{\text {total }}^{2}}$

The type B genetic correlation for the clone effect was estimated as:

$$
r_{B c}=\frac{\widehat{\sigma}_{c}^{2}}{\widehat{\sigma}_{c}^{2}+\widehat{\sigma}_{S * c}^{2}}
$$

Where,

$\hat{\sigma}_{c}^{2} \quad=$ variance due to the clone effect;

$\hat{\sigma}_{s * c}^{2}=$ variance due to the clone by site interaction effect.

PROC CORR (SAS InstituTE, 2002) in SAS was used to estimate the Pearson correlation coefficients for volume between selected $E$. grandis $\mathrm{x} E$. urophylla ortets and their ramets.

\section{Results}

Descriptive statistics of Eucalyptus grandis $x$ E. urophylla seedling and clonal trials

Descriptive statistics for $\mathrm{DBH}$, height, tree volume and survival of the $E$. grandis $\times$ E. urophylla seedling progeny trials and clonal trials are presented in Table 4 and Table 5 respectively. The survival rates ranged between $79.4 \%$ and $92.3 \%$ for the seedling progeny trials and between $75.7 \%$ and $95.5 \%$ for the clonal trials. The mean DBH (age $=7$ years) for the seedling and clonal trials with the best growth rates was $24.5 \mathrm{~cm}(\mathrm{SD}=4.65)$ and $17.38(\mathrm{SD}=3.7)$ respectively. The lowest mean DBH was $17.6 \mathrm{~cm}$ $(\mathrm{SD}=5.61)$ for the seedling progeny trials and

Table 4. - Means and ranges from the E. grandis $\mathrm{x}$ E. urophylla seedling progeny trials for diameter at breast height ( $\mathrm{DBH}$ in $\mathrm{cm})$, height $(\mathrm{m})$ and tree volume $\left(\mathrm{m}^{3}\right)$.

\begin{tabular}{|c|c|c|c|c|c|c|c|c|c|c|c|c|c|}
\hline Site & $N$ & Age & $\mathrm{DBH}$ & SD & Range & Height & SD & Range & Volume & 50 & Range & Survival & $\mathrm{SD}$ \\
\hline PE062A & 1290 & 7 & 19.9 & 5.07 & $\begin{array}{l}5.7- \\
33.5\end{array}$ & 25.1 & 6.26 & $\begin{array}{l}9.7- \\
36.9\end{array}$ & 0.369 & 0.247 & $\begin{array}{l}0.011- \\
1.273\end{array}$ & 80.8 & 39.42 \\
\hline PE062B & 1080 & 7 & 24.5 & 4.65 & $\begin{array}{l}9.2- \\
36.4\end{array}$ & 20.9 & 5.29 & $\begin{array}{l}9.7- \\
34.0\end{array}$ & 0.44 & 0.231 & $\begin{array}{l}0.029- \\
1.181\end{array}$ & 86.5 & 34.21 \\
\hline PE080A & 1728 & 4 & 14.6 & 2.51 & $\begin{array}{l}5.3- \\
20.4\end{array}$ & 17.1 & 2.03 & $\begin{array}{l}7.3- \\
20.9\end{array}$ & 0.121 & 0.044 & $\begin{array}{l}0.007- \\
0.260\end{array}$ & 92.3 & 26.61 \\
\hline PE080B & 1224 & 4 & 13.6 & 2.05 & $\begin{array}{l}6.2- \\
18.9\end{array}$ & 13.9 & 1.23 & $\begin{array}{l}6.6- \\
18.1\end{array}$ & 0.085 & 0.028 & $\begin{array}{l}0.009- \\
0.184\end{array}$ & 79.4 & 40.45 \\
\hline PEOBDC & 894 & 4 & 11.2 & 2.05 & $\begin{array}{l}5.2- \\
16.5\end{array}$ & 132 & 1.73 & $\begin{array}{l}5.8- \\
18.1\end{array}$ & 0.056 & 0.023 & $\begin{array}{l}0.005- \\
0.128\end{array}$ & 88.8 & 31.51 \\
\hline PE109A & 396 & 7 & 17.6 & 5.61 & $\begin{array}{l}7.1- \\
29.9\end{array}$ & 24.1 & 6.03 & $\begin{array}{l}10.1- \\
35.6\end{array}$ & 0.293 & 0.216 & $\begin{array}{l}0.016- \\
0.904\end{array}$ & 88.9 & 31.41 \\
\hline PE109B & 228 & 7 & 17.9 & 5.59 & $\begin{array}{l}7.5- \\
29.2 \\
\end{array}$ & 23.2 & 5.34 & $\begin{array}{l}10.5- \\
32.7 \\
\end{array}$ & 0.288 & 0.211 & $\begin{array}{l}0.018- \\
0.842\end{array}$ & 88.2 & 32.42 \\
\hline
\end{tabular}


Table 5. - Means and ranges of the E. grandis x E. urophylla clonal trials for diameter at breast height (DBH in $\mathrm{cm})$, height $(\mathrm{m})$, tree volume $\left(\mathrm{m}^{3}\right)$ and survival $(\%)$.

\begin{tabular}{|c|c|c|c|c|c|c|c|c|c|c|c|c|c|}
\hline Silte & $N$ & Agu & $\mathrm{DBH}$ & 30 & Rarge & Height & so & Range & Vuluric: & $S 0$ & Rarge & Sùrival & $\mathrm{SO}$ \\
\hline \multirow{2}{*}{ IC35BAKLWA } & 1228 & 4 & 13.93 & 2.62 & $6.1-2 * 3$ & $18.3 ?$ & 2.08 & $8.68-22.5$ & 0.12 & 0.05 & $0.011-0.314$ & 90.29 & 29.61 \\
\hline & $12 \%$ & 7 & 1554 & 357 & $6 ?>71$ & & & & & & & 8985 & 3021 \\
\hline \multirow{2}{*}{ ICJ5ВЕКИ, } & 1224 & 4 & 13.19 & 2.2 .3 & $5.6-19.2$ & 17.26 & 1.81 & $8.12-21.9$ & 0.10 & 0.04 & 0.009 .0 .236 & 90.22 & 29.71 \\
\hline & 1196 & 7 & 15.00 & 3.17 & $5.8-25$ & & & & & & & 87.94 & 32.58 \\
\hline \multirow{2}{*}{ IC $35 \mathrm{BCMTZ}$} & 1233 & 4 & 12.15 & .65 & $6-168$ & 14.54 & 1.16 & $8.4-17.5$ & 0.07 & 0.02 & $0.000-0.15^{\prime}$ & 90.65 & 29.11 \\
\hline & 1173 & 7 & 1399 & 248 & 6205 & & & & & & & $80 ? 5$ & $3<45$ \\
\hline \multirow{2}{*}{ |C35BDMI $\angle$} & 1114 & 4 & 12.56 & 2.11 & $5.5-19.5$ & 15.26 & 1.48 & $7.7-19.9$ & 0.08 & 0.0 .3 & 0.007 .0 .258 & 81.91 & 35.51 \\
\hline & 1030 & 7 & 14.58 & 3.20 & $5.5-24.2$ & & & & & & & 75.74 & 42.88 \\
\hline \multirow{2}{*}{ IC358EPCF } & 1078 & 4 & 1385 & 3.05 & $5.1-20.7$ & 16.46 & 2.20 & $9-21.7$ & 0.11 & 0.05 & $0.008-0.285$ & 79.26 & 20.56 \\
\hline & $103 ?$ & 7 & 1535 & 363 & 63754 & & & & & & & 7588 & 4280 \\
\hline \multirow{2}{*}{ IC35Bトトレ } & 1090 & 4 & 13.72 & 2.84 & 5. $1-20.8$ & 15.93 & 2.12 & $8.26-21.4$ & 0.10 & c. 0.5 & $0.098 \cdot 0.286$ & 80.15 & 39.90 \\
\hline & 1046 & 7 & 15.89 & 3.22 & $5.9-26.7$ & & & & & & & 76.91 & 42.16 \\
\hline \multirow{2}{*}{ ICs61MKWin } & 1605 & 4 & $1<.05$ & 2.51 & $6-20.6$ & 18.78 & 2.09 & $9.8-227$ & 0.12 & 0.05 & $0.012-0.295$ & 94.47 & 22.80 \\
\hline & 1601 & 7 & 1592 & 3.69 & $62-27.1$ & & & & & & & 94.18 & 23.43 \\
\hline \multirow{2}{*}{ 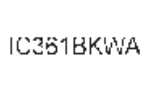 } & 1623 & 4 & 1496 & 260 & $5.5-2.5$ & 14.30 & 1.99 & $11-22.9$ & 014 & 0.06 & $0.01-0332$ & 95.47 & 20.80 \\
\hline & 1602 & $r$ & 16.95 & 3.13 & $5.5-2 i$ & & & & & & & 94.20 & 23.36 \\
\hline \multirow{2}{*}{ ІC861СРГF } & 1592 & 4 & 10.33 & .48 & $5.4-15.4$ & 11.93 & 0.86 & $8-4.2$ & 0.04 & 0.01 & $0.009-0.109$ & 93.65 & 24.40 \\
\hline & 1537 & 7 & 12.44 & 2.22 & $5.0-19.5$ & & & & & & & 90.30 & 29.53 \\
\hline \multirow{2}{*}{ |C3รั1LPDP } & 1351 & 4 & 14.87 & 2.59 & $5.3-2^{4}-4$ & 17.31 & 1.69 & $9-21.9$ & 0.13 & 0.05 & $0.009-2.29$ & 79.41 & 40.45 \\
\hline & 1358 & $r$ & $1 / 38$ & 3.12 & $5.3-2 i$ & & & & & & & $18 . / 1$ & 40.95 \\
\hline \multirow{2}{*}{ IOS6-Fr'T7 } & 1575 & 4 & 12.37 & 2.32 & $5.5-20.5$ & 15.72 & 1.52 & $9.2-19.6$ & 0.08 & 0.03 & $0.01-0.259$ & 92.71 & 26.01 \\
\hline & 1528 & 7 & 14.90 & 3.57 & $5.5-28$ & & & & & & & 89.88 & 30.17 \\
\hline \multirow{2}{*}{$|C 351+4|$} & 1609 & 4 & 12.51 & 2.27 & $5.3-10.5$ & 16.29 & 1.97 & $7.3-20.1$ & 0.09 & 0.04 & $0.008-0.215$ & 94.65 & 22.52 \\
\hline & 15,32 & $r$ & 14,46 & 3.22 & $5.5-22.5$ & & & & & & & 90.00 & 20.95 \\
\hline ICЗO5ATEZ & $\angle 39$ & 4 & 10.75 & .90 & 5.415 .9 & 14.48 & 1.61 & 10.118 .7 & 0.00 & 0.02 & 0.0090 .149 & 91.46 & 27.98 \\
\hline IC365BFSN & 452 & 4 & 12.57 & 2.83 & $5 . \overline{5}-19$ & 16.07 & 2.09 & $10.2-21.3$ & 009 & 0.04 & $0.009-0.242$ & 91.17 & 23.46 \\
\hline ICSG5CL NW & 442 & 4 & 11.20 & 2.4 & $5.9-16.5$ & 14.85 & 1.58 & $10.5-19.2$ & 006 & 3.03 & $0.012-9.165$ & 92.05 & 27.08 \\
\hline |C365СРDГ & 395 & 4 & 16.06 & 3.64 & $6.1-24 . /$ & \&.86 & 3.00 & 10. $i-25.9$ & $0 * i$ & 5.09 & $0.612-0.499$ & 31.80 & $3 B .56$ \\
\hline IC3O5El'TZ & $\angle 01$ & 4 & $13 \angle 5$ & 2.40 & 5.219 .1 & 16.71 & 2.02 & 9.921 .4 & 0.10 & 0.04 & 0.0080 .246 & 83.54 & 37.12 \\
\hline IC365FFDF & $\therefore 19$ & 4 & 15.55 & 2.80 & $5.8-23.3$ & 18.52 & 2.30 & $10.4-24.8$ & 0.15 & 0.07 & $0.011-0.424$ & 87.29 & 33.34 \\
\hline ICJO5G & $40 \bar{r}$ & 4 & 15.20 & 3.24 & $5.7-23.2$ & 16.20 & $2.6 \bar{t}$ & $10.3-24.7$ & 0.15 & 0.07 & $0.011-0.419$ & 54.70 & 35.95 \\
\hline IC36bl IDUK & 430 & 4 & $11, / 4$ & 2.35 & $5.5-18.3$ & 5.30 & 1.93 & $10.2-20.1$ & $0.0 \%$ & 5,03 & $0.01-0.218$ & 91.25 & 28.29 \\
\hline
\end{tabular}

$12.4 \mathrm{~cm}(\mathrm{SD}=2.22)$ for the clonal trials. Overall, the standard deviations were higher for the seedling progeny trials (between 4.65 and 5.61) than for the clonal trials (between 2.22 and 3.82 ) for $\mathrm{DBH}$ at 7 years of age. A similar pattern was seen for height and tree volume.

\section{Variance component estimates and genetic parameters of Eucalyptus grandis $x$} E. urophylla seedling and clonal populations

Variance component estimates and genetic parameters are presented in Tables 6 and 7 for the $E$. grandis $\mathrm{x} E$. urophylla seedling population, and in Tables 8 and 9 for the clonal population. The female variance component estimates $\left(\hat{\sigma}_{f}^{2}\right)$ for the $E$. grandis hybrid parents were insignificant for the seedling $(p<0.409$ for $\mathrm{DBH})$ and clonal $(p<0.188$ for $\mathrm{DBH})$ populations (Tables 6 and 8). The estimates of the female variance components ranged between zero (height and volume) and $0.76(\mathrm{DBH})$ for the seedling population, and between 0.43 (height) and 26.55 (volume) for the clonal population. Consequently, the additive genetic variance and narrow-sense heritability were also low for the $E$. grandis hybrid parents in the seedling population $\left(\hat{\sigma}_{A f}^{2}=3.04\right.$ and $h_{f}^{2}=0.005$ for $\mathrm{DBH})$ and the clonal population $\left(\hat{\sigma}_{A f}^{2}=15.12\right.$ and $h_{f}^{2}=0.05$ for $\mathrm{DBH}$ ) as presented in Tables 7 and 9 .

The GCA estimates of the same $E$. grandis parents used in this study were between $-9 \%$ 
Table 6. - Variance components of the random effects of the E. grandis x E. urophylla hybrid seedling population for diameter at breast height $(\mathrm{DBH})$, height and tree volume.

\begin{tabular}{|c|c|c|c|c|c|}
\hline & Effect & Estimate & $\mathrm{SE}$ & ZValue & ProbZ \\
\hline \multirow{5}{*}{$\mathrm{DBH}$} & female & 0.76 & 3.29 & 0.23 & 0.409 \\
\hline & male & 32.61 & 21.07 & 1.55 & 0.061 \\
\hline & $\begin{array}{c}\text { full sib hybrid } \\
\text { families }\end{array}$ & 30.93 & 975 & 3.17 & 0.001 \\
\hline & $\begin{array}{l}\text { site*full sib hybrid } \\
\text { families }\end{array}$ & 10.72 & 4.73 & 2.27 & 0.012 \\
\hline & error & 533.64 & 11.15 & 47.86 & $<0,001$ \\
\hline \multirow{5}{*}{ Height } & female & 0 & & & \\
\hline & male & 16.56 & 10.86 & 1.52 & 0.064 \\
\hline & $\begin{array}{c}\text { full sib hybrid } \\
\text { families }\end{array}$ & 21.75 & 5.89 & 3.69 & $<0.001$ \\
\hline & $\begin{array}{c}\text { site*full sib hybrid } \\
\text { families }\end{array}$ & 7.06 & 2.84 & 2.40 & 0.008 \\
\hline & error & 312.53 & 0.53 & 47.87 & $<0.001$ \\
\hline \multirow{5}{*}{ Volume } & female & $5.32 \mathrm{E}-17$ & & & \\
\hline & male & 194.24 & 114.46 & 1.70 & 0.045 \\
\hline & $\begin{array}{c}\text { full sib hybrid } \\
\text { families }\end{array}$ & 205.97 & 54.90 & 3.75 & $<0.001$ \\
\hline & $\begin{array}{l}\text { site*full sib hybrid } \\
\text { families }\end{array}$ & 40.32 & 22.63 & 1.78 & 0.037 \\
\hline & error & 2797.50 & 58.46 & 47.86 & $<0.001$ \\
\hline
\end{tabular}

and $12 \%$ and narrow-sense heritability 0.24 for volume in a full-sib pure species population (VAN DEN BERG et al., in press). This is an indication that selecting for additive gene effects based on the $E$. grandis pure species parent performance may not necessary lead to genetic gains in growth if the same $E$. grandis parents are used as hybrid partners with E. urophylla. However, it must be born in mind that the $E$. grandis parents were selected from a second generation improved population and could allow for a more homogeneous population than the E. urophylla parents.

The genetic contribution to growth from the E. urophylla hybrid parents was significant ( $p<0.05$ for volume) for the seedling population, but not for the clonal population (Tables 6 and 8). Narrow-sense heritability for the E. urophylla hybrid parents in the seedling population was 0.24 for tree volume (Table 7) and 0.07 in the clonal population (Table 9). On average however, additive genetic variance $\left(\hat{\sigma}_{A}^{2}=388.48\right)$ only explained $32 \%$ of the total genetic variation $\left(\hat{\sigma}_{G}^{2}=1212.34\right)$ in the seedling population and narrow-sense heritability using the combined female and male additive effect was estimated at 0.12 for volume (Table 7). In the case of the clonal population, additive genetic varia- tion $\left(\hat{\sigma}_{A}^{2}=109.56\right)$ only explained $29 \%$ of the total genetic variance $\left(\hat{\sigma}_{G}^{2}=379.40\right)$ for volume at four years (Table 9). However, when the additive genetic variance was investigated in the clonal population, the progeny of $E$. grandis and $E$. urophylla hybrid parents performed similar with narrow-sense heritabilities estimated at 0.06 and 0.07 respectively for volume at four years.

A potential reason for the relatively low overall additive genetic variation could be due to the reduced genetic base of the parent populations. Parents were selected for growth, good form and resistance to parasites. This selection process allowed for a more homogeneous population for growth traits of the $E$. grandis and E. urophylla parents.

The genetic control of full-sib $E$. grandis $\mathrm{x}$ E. urophylla families was highly significant $(p<0.001)$ for all growth traits in the seedling population (Table 6). The ratio of dominance variance to total variance $\left(d^{2}\right)$ were estimated at 0.20 for $\mathrm{DBH}, 0.24$ for height and 0.25 for tree volume (Table 7). Dominance variance $\left(\hat{\sigma}_{D}^{2}=823.86\right)$ accounted for $68 \%$ of the total genetic variance $\left(\hat{\sigma}_{G}^{2}=1212.34\right)$ for volume. The full-sib hybrid family growth performance in 
the seedling population was relatively stable across sites and little GxE was detected $\left(r_{B f m}=0.74\right.$ for $\mathrm{DBH}, 0.75$ for height and 0.84 for volume).
In the case of $E$. grandis $\mathrm{x} E$. urophylla clonal population, non-additive genetic variation $\left(\hat{\sigma}_{N A}^{2}=269.84\right)$ explained $71 \%$ of the total genetic variation $\left(\hat{\sigma}_{G}^{2}=379.40\right)$ of the four year

Table 7. - Genetic parameters of the E. grandis x E. urophylla hybrid seedling population for diameter at breast height (DBH), height and tree volume. $\hat{\sigma}_{A f}^{2}$ or $\hat{\sigma}_{A m}^{2}=$ additive genetic variance due to the female or male effect, $h_{f}^{2}$ or $h_{m}^{2}=$ narrow-sense heritability for female or male half sibs, $\hat{\sigma}_{D}^{2}=$ dominance genetic variance, $d^{2}=$ ration of dominance variance to total phenotypic variance, $r_{B f m}=$ type B correlation for the full sib families $\mathrm{x}$ site interaction $\hat{\sigma}_{A}^{2}=$ additive genetic variance combining the female and male effect, $h_{i}^{2}=$ narrow-sense heritability for the combined female and male effects, $\hat{\sigma}_{G}^{2}=$ total genetic variance and $H_{i}^{2}=$ broad-sense heritability.

\begin{tabular}{|c|c|c|c|}
\hline female (E. grandis) & $\mathrm{DBH}$ & Height & Volume \\
\hline$\sigma_{A t}^{2}$ & $3.04 \pm 13.27$ & 0 & 0 \\
\hline$\mu_{i}^{2}$ & $0.005 \pm 0.02$ & 0 & 0 \\
\hline \multicolumn{4}{|l|}{ male (E. urophylia) } \\
\hline$\hat{\sigma}_{A m 1}^{2}$ & $130.46 \pm 84.29$ & $66.22 \pm 43.45$ & $776.97 \pm 457.83$ \\
\hline$h_{i \pi}^{2}$ & $0.21 \pm 0.14$ & $0.19 \pm 0.12$ & $0.24 \pm 0.14$ \\
\hline \multicolumn{4}{|l|}{ full sib hybrid families } \\
\hline$\vec{\sigma}_{j 1}^{\gamma}$ & $123.71 \pm 38.98$ & $86.98 \pm 23.67$ & $823.86 \pm 219.59$ \\
\hline$d^{2}$ & $0.20 \pm 0.06$ & $0.24 \pm 0.07$ & $0.25 \pm 0.07$ \\
\hline$r_{B_{j} ; m}$ & 0.74 & 0.75 & 0.84 \\
\hline$\hat{a}_{A}^{i}$ & 66.75 & 33.11 & 388.48 \\
\hline$h_{i}^{2}$ & 0.11 & 0.09 & 0.12 \\
\hline$\hat{\sigma}_{u}^{2}$ & 19045 & 120.09 & 1212.34 \\
\hline$H_{i}^{*}$ & 0.31 & 0.34 & 0.37 \\
\hline$\theta_{1}^{2}$ & 608.67 & 357.89 & 3238.03 \\
\hline
\end{tabular}

Table 8. - Variance components of the random effects of the E. grandis $\mathrm{x} E$. urophylla hybrid clonal population for diameter at breast height (DBH), height and tree volume.

\begin{tabular}{|c|c|c|c|c|c|}
\hline & Effect & Estimate & StdErr & ZValue & ProbZ \\
\hline \multirow{7}{*}{$\mathrm{DBH}$} & female & 3.78 & 4.27 & 0.89 & 0.188 \\
\hline & male & 5.42 & 4.37 & 1.24 & 0.108 \\
\hline & full sib hybrid families & 2.13 & 5.57 & 0.38 & 0.351 \\
\hline & clone & 36.33 & 5.89 & 6.16 & $\angle 0.001$ \\
\hline & site" wull sib hybrid families & 1.32 & 1.37 & 0.96 & 0.167 \\
\hline & site clone & 18.92 & 2.16 & 8.76 & $<0.001$ \\
\hline & error & 251.49 & 2.94 & 85.46 & $\therefore 0.001$ \\
\hline \multirow{7}{*}{ Height } & female & 0.43 & 1.28 & 0.34 & 0.367 \\
\hline & male & 0.83 & 1.25 & 0.66 & 0.254 \\
\hline & full sib hybrid families & 2.43 & 2.05 & 1.18 & 0.118 \\
\hline & clone & 11.87 & 1.94 & 6.13 & $<0.001$ \\
\hline & site*full sib hybrid families & 0.36 & 0.54 & 0.68 & 0.250 \\
\hline & site ${ }^{*}$ clone & 5.76 & 0.78 & 7.37 & $<0.001$ \\
\hline & error & 97.91 & 1.15 & 85.44 & 40.001 \\
\hline \multirow{7}{*}{ Volume } & female & 26.55 & 27.62 & 0.96 & 0.168 \\
\hline & male & 28.23 & 23.70 & 1.19 & 0.117 \\
\hline & full sib hybrid families & 14.60 & 31.56 & 0.46 & 0.322 \\
\hline & clone & 211.46 & 33,71 & 6.27 & $<0.001$ \\
\hline & site*full sib hybrid families & 4.57 & 7.02 & 0.65 & 0.257 \\
\hline & site ${ }^{*}$ clone & 103.13 & 11.38 & 9.07 & $<0.001$ \\
\hline & error & 1283.82 & 15.02 & 85.48 & $<0.001$ \\
\hline
\end{tabular}


volume data (Table 9). Only $21.6 \%$ of the nonadditive variation $\left(\hat{\sigma}_{N A}^{2}=269.84\right)$ could be explained by the dominance variance $\left(\hat{\sigma}_{D}^{2}=58.39\right)$ and the full-sib hybrid family effect was insignificant as indicated in Table 8. The rest of the non-additive genetic variation was explained by the clone effect $\left(\hat{\sigma}_{c}^{2}=211.46\right.$ for volume) and was highly significant $(p<0.001)$ for the three growth traits (Tables 8 and 9). However, it must be borne in mind that, in many cases, only one or two individuals were selected from a specific cross to test as clones. Hence, the data from this clonal population might be inadequate to partition the non-additive genetic variance into dominance and epistatic genetic variance. In order to try and shed some light onto the nature of non-additive and additive genetic effects, the random clonal effect was dropped from the linear model. It is apparent from Table 9 that when clone effects were dropped from the model, the ratio explained by the dominance variance increased substantially from 0.04 to 0.27 for volume. The narrow-sense heritabilities for the $E$. grandis and the $E$. urophylla hybrid parents stayed low at 0.07 each. This is an indication that effects which the model previously allocated to remaining genetic effects among clones within a family are now mostly being absorbed by the inferred dominance genetic component of variation. This result points to a strong confounding effect between dominance and other epistatic terms present in the clone effect. Nevertheless, results from both the $E$. grandis $\mathrm{x} E$. urophylla seedling and hybrid population indicated that a breeding strategy to capture non-additive genetic effects will be the most appropriate strategy to follow.

\section{Correlation between pure species parents and hybrid parents growth performance}

The above results indicated that when selecting for additive gene effects, E. urophylla hybrid parents played a bigger role than the $E$. grandis hybrid parents when the growth performance of $E$. grandis x $E$. urophylla hybrid seedlings was compared. The success of the current hybrid breeding strategy will however still depend on the correlation between the breeding values of the selected $E$. urophylla pure species parents and the GHA estimates of the E. urophylla hybrid parents.

Table 9. - Genetic parameters of the E. grandis x E. urophylla hybrid clonal population for diameter at breast height $(\mathrm{DBH})$, height and tree volume. $\hat{\sigma}_{A f}^{2}$ or $\hat{\sigma}_{A m}^{2}=$ additive genetic variance due to the female or male effect, $h_{f}^{2}$ or $h_{m}^{2}=$ narrow-sense heritability for female or male half sibs, $\hat{\sigma}_{D}^{2}=$ dominance genetic variance, $d^{2}=$ ration of dominance variance to total phenotypic variance, $r_{B f m}=$ type B correlation for the full sib families $\mathrm{x}$ site interaction, $c^{2}=$ ration of clone variance to total phenotypic variance, $r_{B c}=$ type $\mathrm{B}$ correlation for the clone $\mathrm{x}$ site interaction, $\hat{\sigma}_{A}^{2}=$ additive genetic variance combining the female and male effect, $h_{i}^{2}=$ narrow-sense heritability for the combined female and male effects, $\hat{\sigma}_{G}^{2}=$ total genetic variance and $H_{i}^{2}=$ broad-sense heritability.

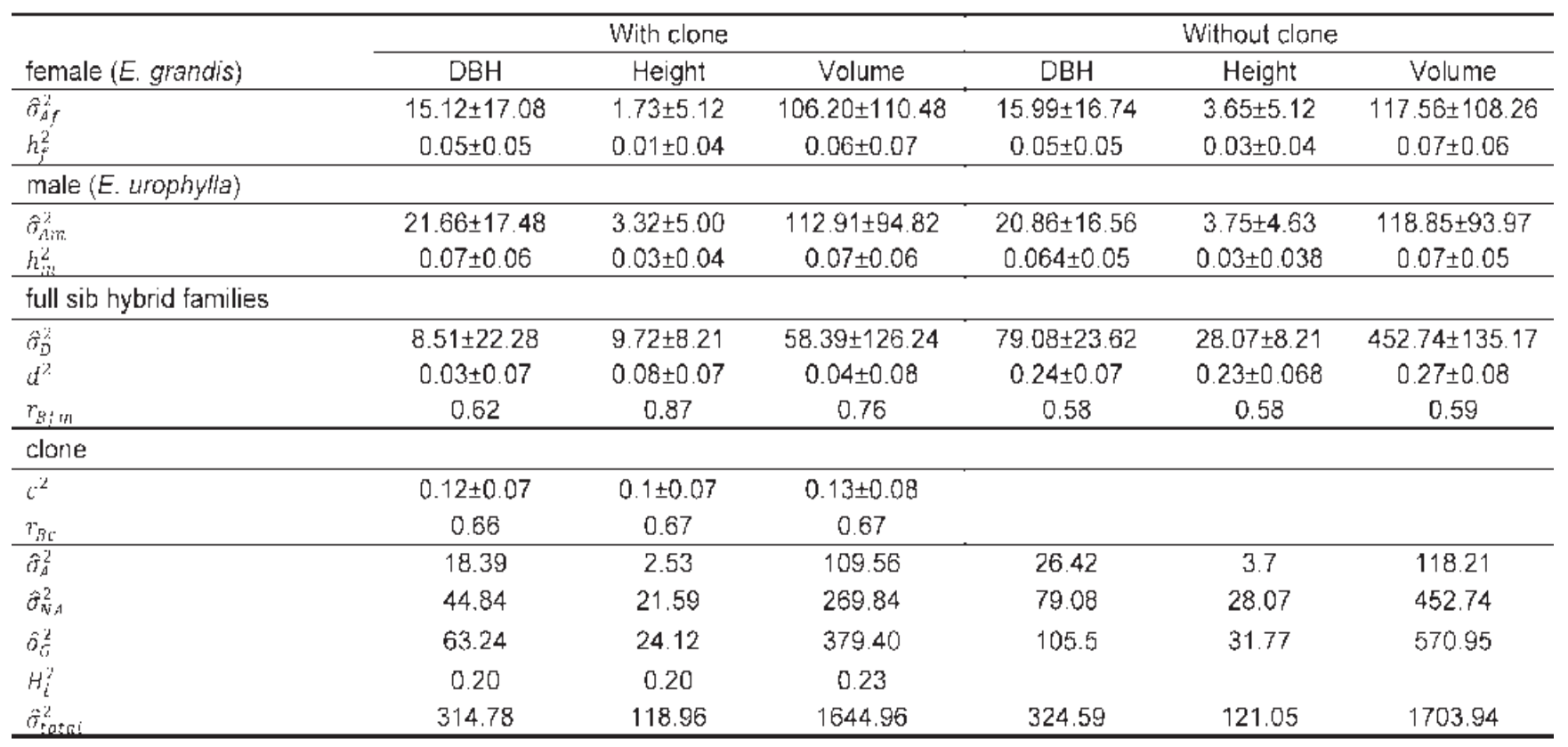


Table 10. - Pearson correlation coefficients between E. urophylla pure species parent family and individual breeding values (BV) and general hybridizing ability (GHA) of the E. urophylla hybrid parents. Prob $>$ lrl under H0: Rho $=0$.

\begin{tabular}{cccccc}
\hline Variable & N & Mean & Range & Correlation with GHA & p-value \\
\hline GHA & 20 & $1.99 \pm 9.45$ & $-17.52-16.08$ & 1 & 0.943 \\
Family BV & 20 & $5.30 \pm 8.84$ & $-7.75-19.69$ & 0.017 & 0.007 \\
Individual BV & 20 & $12.20 \pm 5.74$ & $-3.45-21.60$ & 0.581 & 0.7 \\
\hline
\end{tabular}

Table 11. - Pearson correlation coefficients between $E$. grandis x E. urophylla seedling ortets and their ramets for tree volume. $\mathrm{BV}=$ breeding values, std $=$ standardized data, blup = best linear unbiased prediction estimates . $\mathrm{N}=126$, Prob $>$ lrl under H0: Rho $=0$.

\begin{tabular}{|c|c|c|c|}
\hline & & \multicolumn{2}{|c|}{ Clonal ramets } \\
\hline & & $\begin{array}{l}\text { mean std volume } \\
\text { (Range }-46 \%-54 \% \text { ) }\end{array}$ & $\begin{array}{c}\text { clonal blups } \\
\text { (Range: }-31 \%-38 \% \text { ) }\end{array}$ \\
\hline \multirow{3}{*}{ 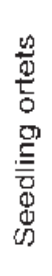 } & $\begin{array}{l}\text { individual std volume } \\
\text { (Range: } 1 \%-197 \% \text { ) }\end{array}$ & $0.3174(p<0.0003)$ & $0.2673(\beta<0.0026)$ \\
\hline & $\begin{array}{c}\text { family bv } \\
\text { (Range: }-25 \%-39.5 \% \text { ) }\end{array}$ & $0.22566(p<0.0114)$ & $0.1522(\beta<0.0901)$ \\
\hline & $\begin{array}{c}\text { individual bv } \\
\text { (Range: }-8 \%-61 \%)\end{array}$ & $0.3355(p<0.0001)$ & $0.2481(p<0.0053)$ \\
\hline
\end{tabular}

In our study, the Pearson correlation between predicted individual breeding values of the E. urophylla pure species parents and the GHA of the E. urophylla hybrid parents was estimated at $0.58(p<0.007)$ as indicated in Table 10. The individual breeding values of the selected $E$. urophylla pure species parents ranged between $-3.5 \%$ to $21.6 \%$ gain (VAN DEN BERG et al., 2016). However, the correlation between family breeding values of the $E$. urophylla pure species families and the GHA estimates of the $E$. urophylla hybrid parents were lower $(0.02, p<0.943)$, even though the range of the $E$. urophylla family breeding values $(-7.8 \%$ to $19.7 \%$ ) were similar to that of the individual breeding values as estimated by VAN DEN BERG et al. (2016).

This result suggests that individual breeding values of the $E$. urophylla pure species are relatively good indicators of $E$. urophylla parent performance as hybrid partners with $E$. grandis if tree volume is the trait of interest. Hence, the selection for additive gene effects of $E$. urophylla pure species parents will lead to genetic gains in growth traits of $E$. grandis $\mathrm{x} E$. urophylla hybrid seedlings derived from the selected E. urophylla parents. However, these results are based on the performance of the $E$. grandis $\mathrm{x} E$. urophylla hybrid seedling population. In most countries, interspecific hybrids of $E$. grandis x $E$. urophylla are commercially deployed as clones, and an important factor that should be kept in mind when deciding on the best $E$. grandis x $E$. urophylla hybrid breeding strategy is the correlation between the selected ortet and the ramets of the ortet.

\section{Correlation between the standardised volumes and BLUPs of E. grandis $x E$. urophylla ortet and ramets}

The individual tree volume of $126 E$. grandis $\mathrm{x}$ $E$. urophylla seedling ortets and the mean tree volume of their ramets were used to estimate the phenotypic correlation between ortets and their ramets (Table 11). Standardised data were used to estimate the Pearson correlation coefficients. The percentage gain in individual tree volume of the selected seedling ortets that were used in calculating the correlation coefficients ranged between $1 \%$ and $197 \%$ over the $E$. grandis x E. urophylla hybrid seedling population 
mean. The tree volume means of their ramets ranged between $-46 \%$ and $54 \%$ over the clonal population mean. The phenotypic correlation between the individual tree volumes of the ortets and the mean tree volumes of their ramets was positive and estimated at 0.3174 $(\mathrm{p}<0.0003)$.

In addition to the phenotypic correlations, the family and individual breeding values of the $E$. grandis x $E$. urophylla seedling ortets were correlated (Pearson) to the mean clonal BLUP estimates of their ramets. Clonal individual and family breeding values could not be calculated due to the insignificance $(p<0.322)$ of the fullsib hybrid family effect in the clonal population. For the same reason, a reliable genetic correlation between $E$. grandis x $E$. urophylla hybrid ortets and ramets could not be calculated.

The family breeding values of the seedling population ranged between $-25 \%$ and $39.5 \%$, and between $-8 \%$ and $61 \%$ for the individual breeding values (Table 11). The mean clonal BLUP estimates for the clonal population ranged between $-31 \%$ and $38 \%$. A correlation coefficient of $0.1522(p<0.0901)$ was detected between the ortet family breeding values and the mean BLUP estimates of their ramets. In the case of individual breeding values, a higher correlation coefficient of $0.2481(p<0.0053)$ was estimated between the ortet individual breeding values and the mean BLUP estimates of the clones. The best correlation coefficient $(0.3355$, $p<0.0001$ ) however, was detected between the individual breeding values of the ortets and the mean tree volumes of their ramets.

In general, the correlation between seedling ortets and their ramets was relatively weak for all the variables used and is an indicator that the best seedling does not necessary produce the best clone. The feasibility of selection at seedling level therefore needs to be investigated.

\section{Discussion}

The results from our study indicated that nonadditive genetic variation explained majority of the genetic variation present in $E$. grandis $\mathrm{x}$ E. urophylla seedling and clonal populations. The same phenomenon was found by other authors for $E$. grandis x $E$. urophylla hybrid seedlings (BOUvET et al., 2009; RETIEF and
Stanger, 2009; Rezende and DE RESEnde, 2000; Vigneron et al., 2000). RETIEF and StANGER (2009) reported that dominance genetic effects accounted for nearly $60 \%$ of the total genetic variance in the $E$. grandis x $E$. urophylla hybrid factorial of their study in Zululand. BouvET et al. (2009) reported an average $\hat{\sigma}_{D}^{2} / \hat{\sigma}_{A}^{2}$ ratio of 1.2 for a relatively large $E$. grandis x $E$. urophylla hybrid seedling population (684 families). One explanation of the high dominance variance could be due to the nature of dominance variance. The dominance effect between alleles and their frequency will determine the magnitude of the dominance variance $(\mathrm{LYNCH}$ and WALSH, 1998). Dominance variance exceeds additive variance in the case of overdominance and/or in the case of total dominance when frequencies of alleles are different when a model of one locus and two alleles are used ( $\mathrm{LYNCH}$ and WALSH, 1998). Although the case of overdominance must be considered with caution (BIRCHLE et al., 2006), it may explain some of the relatively high dominance variance present in perennial plants such as Eucalyptus (BOUvET et al., 2009). Nevertheless, these results indicate that a breeding strategy to capture nonadditive genetic effects in the hybrid will be the most appropriate strategy to follow. Three strategies that could potentially exploit nonadditive variance are RRS (COMSTOCK et al., 1949), reciprocal recurrent selection with forward selection (RRS-SF; NIKLES, 1992) and the development and crossing of inbred lines. The implications of these strategies for tree improvement have been discussed by various authors (DUNGEY et al., 2000; HetTASCH et al., 2005; NIKLES, 1992; SHELbOURNE, 2000; Vigneron, 1991). KeRR et al. (2004) did a simulation study comparing RRS, RRS-SF, recurrent selection for general combining ability (RSGCA; JENKINS, 1940) and the hybrid swarm strategy over five cycles of breeding. Results from this study suggest that the RRS-SF strategy yielded the highest genetic gains per year in cases where non-additive variance is higher than additive variance and when the purehybrid correlations are negative or close to zero. However, the latter was not cost efficient at all.

Another important factor to consider when developing an interspecific hybrid breeding strategy is the weak correlations that were detected between $E$. grandis x $E$. urophylla hybrid seedling ortets and their ramets in our study. One possible reason for the weak correla- 
tion is the degree of environmental influence that was present in the $E$. grandis x $E$. urophylla hybrid seedling population. The $H^{2}{ }_{i}$ was estimated as 0.37 and the $h^{2}{ }_{i}$ as 0.12 in the seedling population. This is an indication that majority of the variance in the $E$. grandis $\mathrm{x}$ E. urophylla hybrid seedling population was explained by environmental noise and could have an impact on the ortet-ramet phenotypic correlation. Although we did investigate the correlation between family and individual breeding values of the $E$. grandis x $E$. urophylla hybrid seedling ortets and the clonal BLUP estimates of their ramets, a more detailed study is necessary to investigate the genetic correlation between eucalypts hybrid seedling ortets and their ramets.

Another fundamental difference between seedlings and clones that could potentially influence the correlation between ortet and ramets, is the structure of their root system (HARTMANN et al., 1990). SASSE and SANDS (1997) reported that $E$. globulus seedlings had strongly gravitropic tap-roots, with two types of primary roots from which secondary roots emerged. Clones had no tap roots, but it had adventitious roots that were formed during propagation. GrossNiCKLE and RUSSELL (1990) found that cuttings of Chamaecyparis nootkatensis produced less new root area than seedlings over 21 days. FULleR and LitTLE (2007) also reported that $E$. grandis seedlings had significantly longer roots than micro-cuttings, as well as a better distribution around the plug. However, no significance in growth was reported in their study. GASPAR et al. (2005) also reported that there was no significant difference between $E$. globulus cuttings and seedlings for growth and wood density. SASSE and SANDS (1996) conducted a study to test the responses of $E$. globulus cuttings and seedlings to water stress and reported that the seedlings had greater water use than cuttings in the water stress treatments. However, in all these studies cuttings were produced from different individuals with a similar genetic makeup than the seedlings of a pure species population. No direct comparison of ortets and their ramets have been reported on. Other effects associated with cloning such as rooting ability of different individuals and $\mathrm{C}$ effects could also contribute to the difference in growth performance between $E$. grandis x $E$. urophylla seedling ortets and their ramets. $\mathrm{C}$ effects are related to non-genetic sources of covariance between ramets of the same clone and may be due to factors such as the age or the environment of the original ortet (Costa E Silva et al., 2004). When C effects are present, it may inflate estimates of between-clone variances (LIBBY and JUND, 1962; BuRdon and SHELbOURNE, 1974), and may upwardly bias epistatic genetic variance estimates (CosTA E SILVA et al., 2004). Inequalities among propagules within clones due to ontogenic factors such as cutting position on the ortet or morphological factors such as cutting size may also arise with cloning and could affect growth performance (CosTA E SILVA et al., 2004). Nevertheless, if the correlation between the selected $E$. grandis x $E$. urophylla seedling ortet and their ramets are weak as suggested in our study, then the feasibility of selection at seedling level needs to be investigated.

\section{Conclusions}

The study was set out to review the current $E$. grandis and E. urophyla hybrid breeding strategy used in South Africa and has identified key areas to investigate.

Information on genetic parameters of $E$. grandis x $E$. urophylla hybrid seedling and clonal populations needed quantification. The purehybrid and ortet-ramet correlation values are essential to develop a suitable hybrid breeding strategy and were explored in this study. The general theoretical literature on this subject and specifically in the context of $E$. grandis $\mathrm{x}$ $E$. urophylla hybrid clonal populations is inconclusive on several vital questions within the hybrid breeding discourse. The study sought to answer some of these questions.

Results from our study indicated that nonadditive variance plays a major role in determining the growth performance of $E$. grandis $\mathrm{x}$ $E$. urophylla hybrid seedlings and clones. Due to the pre-eminence of non-additive variance, the pure-hybrid correlations were weak, especially for clonal populations. It would therefore seem that GCA or individual breeding values are not good predictors of GHA for growth performance in the observed populations. Results from this study also indicated a weak ortetramet correlation for $E$. grandis x $E$. urophylla hybrids. This suggests that the current strategy to first screen $E$. grandis x $E$. urophylla seedlings in progeny trials should be revisited. 
Although our study has offered an evaluative perspective on Eucalyptus hybrid breeding, it encountered a number of limitations, which need to be considered.

Firstly, all the E. grandis and E. urophylla parents used for interspecific crossing were selected on their mature age phenotypes for growth and tree form. This selection process might explain the lack of additive variance present in the observed $E$. grandis x $E$. urophylla hybrid populations.

Secondly, in view of the selected nature of $E$. grandis $\mathrm{x} E$. urophylla ortets and the limited numbers of individuals per family, results on the $E$. grandis $\mathrm{x} E$. urophylla clonal populations must be interpreted cautiously. Due to this limitation, the family effect of clonal populations was insignificant, and ortet-ramet correlations were restricted to phenotypic correlations.

The scale of this debate is therefore extensive and to develop a suitable and cost effective eucalypt hybrid breeding strategy, there is a need for more case studies to allow further assessments of this subject.

In spite of the limitations of this study, it has attained its primary objective namely: to review the current hybrid breeding strategy. From the results of the study, the overall recommendation is to adopt a hybrid breeding strategy that captures non-additive genetic effects in combination with a strategy that minimises the testing time of $E$. grandis x $E$. urophylla hybrid material as seedlings.

\section{Acknowledgements}

The authors thank the Mondi Research Team for assistance with trial establishment and measurements. They also thank the Mondi management team for making the data available and for constant report. Funding was provided by Mondi training department.

\section{References}

Birchle, J. A., H. YAO and S. Chudalayandi (2006): Unraveling the genetic basis of hybrid vigor. Proceedings of National Academy of Science USA 103: 12957-12958.

Bison, O., M. A. P. Ramalho, G. D. S. P. Rezende, A. M. Aguiar and M. D. V. Deresende (2006): Comparison between open pollinated progenies and hybrid performance in Eucalyptus grandis and Eucalyptus urophylla. Silvae Genetica 55: 192-196.

Bouvet, J. M., A. SAYA and P. H. Vigneron (2009): Trends in additive, dominance and environmental effects with age for growth traits in Eucalyptus hybrid populations. Euphytica 165: 35-54.

Burdon, R. D. and C. J. A. Shelbourne (1974): The use of vegetative propagules for obtaining genetic and Physiological information. New Zealand Journal of Forestry Science 4: 418-425.

Burdon, R. D. (1977): Genetic correlation as a concept for studying genotype-environment interaction in forest tree breeding. Silvae Genetica 26: 168-175.

Comstock, R., H. Robinson and P. Harvey (1949): A breeding procedure design to make maximum use of both general and specific combining ability. Agon Journal 41: 360-367.

Costa e Silva, J., N. M. G. Borralho and B. M. PotTs (2004): Additive and non-additive genetic parameters from clonally replicated and seedling progenies of Eucalyptus globulus. Theoretical and Applied genetics 108(6): 1113-1119.

De Assis, T. F. (2000): Production and use of Eucalyptus hybrids for industrial purposes. In: DUNGEY, H., Dieters, M., Nikles, D. (eds), Proceedings of the QFRI/CRC-SPF Symposium: Hybrid Breeding and Genetics of Forest Trees, 9-14 April 2000, Noosa, Queensland. Australia: Department of Primary Industries. pp 63-74.

Denison, N. P. and J. E. KietzKa (1992): The use and importance of hybrid intensive forestry in South Africa. In: Lambeth, C., Devorak, W. (eds), Proceedings of the IUFRO Conference: Resolving tropical forest resource concerns through tree improvement, gene conservation and domestication of new species, October 1992, Cali, Colombia. pp 348-358.

DiCkerson, G. E. (1969): Techniques for research in quantitative animal genetics. In: Techniques and procedures in animal science research. Albany, New York: American Society of Animal Science. pp 36-79.

Dungey, H. S., J. R. KeRR and M. J. Dieters (2000): A simulation of the comparative gains from three different hybrid breeding schemes (II) Results. In: Dungey, H., Dieters, M., Nikles, D. (eds), Proceedings of the QFRI/CRC-SPF Symposium: Hybrid Breeding and Genetics of Forest Trees, 9-14 April 2000, Noosa, Queensland. Australia: Department of Primary Industries. pp 351-356.

Eisen, E. and A. SAXTON (1983): Genotype x environment interactions and genetic correlations involving two environment factors. Theoretical and Applied Genetics 67: 75-86.

FALCONER, D. S. (1981): Introduction to quantitative genetics. United Kingdom: Longman Scientific \& Technical.

FulleR, G. M. and K. M. LitTle (2007): Fourteen month growth responses of Eucalyptus grandis 
micro-cuttings and seedlings and their interaction with weeding in Zululand, South Africa. ICFR Bulletin 17: 1-25.

Gaspar, M. J., N. Borralho and A. Lopes Gomes (2005): Comparison between field performance of cuttings and seedlings of Eucalyptus globulus. Annals of Forest Science 62: 837-841.

Grossnickle, S. C. and J. H. Russell (1990): Water movement in yellow-cedar seedlings and rooted cuttings: Comparison of whole plant and root system pressurization methods. Tree Physiology 7: 57-68.

Hartmann, H. T., D. E. Kester and F. T. Davies (1990): Plant Propagation Principles and Practices ( $5^{\text {th }}$ edn). Englewood Cliffs: Prentice-Hall.

Hettasch, M. H., K. A. Lunt, B. T. Pierce, C. L. Snedden, D. J. Steyn, H. M. Venter and S. D. VERRYN (2005): Tree Breeding Course Manual. Pretoria: South Africa.

HiLl, W. G. (1984): On selection among groups with heterogeneous variance. Animal Production 39: 473-477.

Hodge, G. R. and W. S. DvoraK (2012): Growth potential and genetic parameters of four Mesoamerican pines planted in the Southern Hemisphere. Southern Forests 74(1): 27-49.

IKEMORI, Y. K. (1984): The new eucalypt forest. In: Proceedings of the Wallenberg Foundation Symposium, Falun, Sweden. The Marcus Wallenberg Foundation. pp 16-20.

JEnkins, M. T. (1940): The segregation of genes affecting yield of grain in maize. Journal of the American Society of Agronomy 32: 55-63.

KerR, R. J., M. J. Dieter and B. TIER (2004): Simulation of the comparative gains from four different hybrid tree breeding strategies. Canadian Journal of Forests Research 34: 209-220.

KHA, L. D. and N. V. CuONG (2000): Research on hybridisation of some Eucalyptus species in Vietnam. In: Dungey, H., Dieters, M., Nikles, D. (eds), Proceedings of the QFRI/CRC-SPF Symposium: Hybrid Breeding and Genetics of Forest Trees, 9-14 April 2000, Noosa, Queensland. Australia: Department of Primary Industries. pp 139-146.

LiBBY, W. J. and E. Jund (1962): Variance associated with cloning. Heredity 17: 533-540.

LYNCH, M. and B. WALSH (1998): Genetics and analysis of quantitative traits. Sunderland: Sinauer Associates.

MAX, T. A. and H. E. BurkHART (1976): Segmented Polynomial Regression Applied to Taper Equations. Forest Science. Vol. 2. pp 283-289.

NikLES, D. G. (1992): Hybrids of forest trees: the bases of hybrid superiority and a discussion of breeding methods. In: Lambeth, C., Devorak, W. (eds). Proceedings of the IUFRO Conference: Resolving tropical forest resource concerns through tree improvement, gene conservation and domestication of new species, October 1992, Raleigh, USA. North Carolina: North Carolina State University. pp 333-347.
PotTs, B. M. and H. S. Dungey (2004): Interspecific hybridization of Euclyptus: key issues for breeders and geneticist. New Forests 27: 115-138.

Potts, B. M., P. W. Volker, P. A. Tilyard and K. JoyCE (2000): The genetics of hybridisation in temperate Eucalyptus. In: Dungey, H., Dieters, M., Nikles, D. (eds). Proceedings of the QFRI/CRC-SPF Symposium: Hybrid Breeding and Genetics of Forest Trees, 9-14 April 2000, Noosa, Queensland. Australia: Department of Primary Industries. pp 200-2011.

Retief, E. C. L. and T. K. Stanger (2009): Genetic parameters of pure and hybrid populations of Eucalyptus grandis and E. urophylla and implications for hybrid breeding strategy. Southern Forests 71(2): 133-140.

Rezende, G. D. S. P. and M. D. V. DE Resende (2000): Dominance effects in Eucalyptus grandis, Eucalyptus urophylla and Hybrids. In: Dungey, H., Dieters, M., Nikles, D. (eds). Proceedings of the QFRI/CRCSPF Symposium: Hybrid Breeding and Genetics of Forest Trees, 9-14 April 2000, Noosa, Queensland. Australia: Department of Primary Industries. pp 93-100

SAS InstiTUTE (2002): SAS 9.1.3 help and documentation. Cary: SAS Institute.

SASSE, J. and R. SANDS (1996): Comparative responses of cuttings and seedlings of Eucalyptus globulus to water stress. Tree Physiology 16: 287-294.

SAsse, J. and R. SANDS (1997): Configuration and development of root systems of cuttings and seedlings of Eucalyptus globulus. New Forests 14: 85-105.

Shelbourne, C. J. A. (2000): Some insights on hybrids in forest tree improvement. In: Dungey, H., Dieters, M., Nikles, D. (eds), Proceedings of the QFRI/CRC-SPF Symposium: Hybrid Breeding and Genetics of Forest Trees, 9-14 April 2000, Noosa, Queensland. Australia: Department of Primary Industries. pp 53-62.

VAn den Berg, G. J., S. D. Verryn, P. W. Chirwa and F. VAN DEVEnTER (2016): Genetic parameters of measures of growth in Eucalyptus urophylla in South Africa. Southern Forests: A Journal of Forest Science. (DOI: 10.2989/20702620.2016. 1162616).

VAN Den Berg, G. J., S. D. Verryn, P. W. ChIrWA and F. VAN DEVENTER (in press): Genetic parameters and genotype by environment interaction of Eucalyptus grandis populations used in intra-specific hybrid production in South Africa. Southern Forests: A Journal of Forest Science.

VERRYN, S. D. (2000): Eucalyptus hybrid breeding in South Africa. In: Dungey, H., Dieters, M., Nikles, D. (eds). Proceedings of the QFRI/CRC-SPF Symposium: Hybrid Breeding and Genetics of Forest Trees, 9-14 April 2000, Noosa, Queensland. Australia: Department of Primary Industries. pp 191-199. 
Vigneron, P. (1991): Creation et amelioration de varieties hybrids d'Eucalyptus au Congo. In: Schönau, A. P. G. (eds). Proceedings of the IUFRO Symposium: Intensive forestry: the role of eucalypts, 2-6 September 1991, Durban, South Africa. Pretoria: Southern African Institute of Forestry. pp 345-360.

Vigneron, P., J. M. Bouvet, R. Gouma, A. Saya, J. M. Gion and D. VerhaEgen (2000): Eucalypt hybrid breeding in Congo. In: Dungey, H., Dieters, M., Nikles, D. (eds). Proceedings of the QFRI/CRC-SPF Symposium: Hybrid Breeding and Genetics of Forest Trees, 9-14 April 2000, Noosa, Queensland. Australia: Department of Primary Industries. pp 14-26.
Volker, P. W. (2002): Quantitative genetics of Eucalyptus globulus, E. nitens and their $\mathrm{F}_{1}$ hybrid. $\mathrm{PhD}$ thesis, University of Tasmania, Australia.

Volker, P. W., B. M. Potts and N. M. G. Borralho (2008): Genetic parameters of intra- and interspecific hybrids of Eucalyptus globulus and E. nitens. Tree Genomics and Genomes 4: 445-460.

White, T. L., W. T. AdAms and D. A. Neale (2007): Forest genetics. Wallingford: CAB International.

Herausgeber: Johann Heinrich von Thünen-Institut. Bundesforschungsinstitut für Ländliche Räume, Wald und Fischerei. Schriftleitung: Institut für Forstgenetik, Sieker Landstrasse 2, D-22927 Grosshansdorf

Verlag: J. D. Sauerländer's Verlag, Berliner Strasse 46, D-63619 Bad Orb Anzeigenverwaltung: J. D. Sauerländer's Verlag, Bad Orb

Gesamtherstellung: PPPP Norbert Wege e.K., Gladenbach — Printed in Germany. 